Cupido, C. N. et al. (2013). Phylogeny of Southern African and Australasian Wahlenbergioids

(Campanulaceae) based on ITS and tran $L-F$ sequence data: implications for a reclassification.

Systematic Botany, 38(2): 523 - 535

http://dx.doi.org/10.1600/036364413X666714

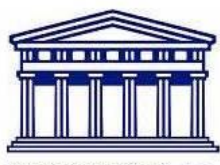

UNIVERSITY of the

WESTERN CAPE

\title{
Phylogeny of Southern African and Australasian Wahlenbergioids (Campanulaceae) based on ITS and trnL-F sequence data: implications for a reclassification
}

\author{
Christopher N. Cupido, Jessica M. Prebble, and William M. M. Eddie
}

\begin{abstract}
The Campanulaceae: Wahlenbergioideae currently comprises 15 genera, one of which, Wahlenbergia, is widespread over the southern continents. Southern Africa is the region with maximum wahlenbergioid diversity with 12 genera and approximately 252 species. A second center is Australasia with 38 Wahlenbergia species. This study used a broad sample of wahlenbergioid diversity from South Africa, Australia, and New Zealand to reconstruct a phylogeny based on chloroplast trnL-F and nuclear ITS sequences. Data were analyzed separately and in combination using parsimony and Bayesian methods. The results suggest that for the wahlenbergioids to be monophyletic Wahlenbergia hederacea has to be excluded and that none of the South African, Australian or New Zealand lineages are strictly monophyletic. There are five species assemblages that are in some disagreement with current classification in the family. Wahlenbergia, Prismatocarpus and Roella are shown to be non-monophyletic and implications for a reclassification are presented. Careful consideration of morphological characters is suggested before the adjustment of generic circumscriptions can be accomplished.
\end{abstract}

Recent family-wide molecular phylogenetic studies have supported the view that the Campanulaceae s.s. can be divided into two major groups on the basis of their pollen morphology: the colpate/colporate platycodonoids and the porate wahlenbergioids and campanuloids (Eddie et al. 2003; Haberle et al. 2009). The two porate groups can be separated mostly by capsule morphology and geographical distribution. The wahlenbergioid group is essentially a southern hemisphere group that comprises 15 genera: Wahlenbergia Schrad. ex Roth; Berenice Tul.; Craterocapsa Hilliard \& B.L.Burtt; Gunillaea Thulin; Heterochaenia A.DC.; Namacodon Thulin; Nesocodon Thulin; Prismatocarpus L'Hé r.; Rhigiophyllum Hochst.; Roella L.; Merciera A.DC.; Microcodon A.DC.; Siphocodon Turcz;; Theilera E.Phillips; and Treichelia Vatke. The porate type of pollen characteristic of the wahlenbergioid taxa is shared with the predominantly northern hemisphere campanuloids (Eddie et al. 2003). Within the wahlenbergioids, pollen morphology has proved useful at the generic level (Hong and Pan 1998) and was primarily used to place Rhigiophyllum and Siphocodon in a separate tribe, the Rhigiophylleae Eddie \& Cupido (Eddie et al. 2010). 
In the southern hemisphere, the present day distribution suggests two centers of wahlenbergioid diversity. Southern Africa is described by Hong (1995) as one of three global centers of diversity and has 252 species assigned to 12 genera of which eight are endemic to this region (Cupido et al. 2011). A second center is Australasia with 38 Wahlenbergia species (Australia 28 species, 27 indigenous and one introduced from South Africa (Smith 1992; Plunkett et al. 2009); New Zealand 10 species (Petterson 1997).

Wahlenbergia (including Lightfootia L'Hé r.), the largest and most widely distributed of the wahlenbergioid genera, consists of 170 species in South Africa (Welman and Cupido 2003; Cupido and Conrad 1999) that occur in the south-western Cape, KwaZulu-Natal, Eastern Cape, Mpumalanga, and Limpopo. Wahlenbergia has an enormous distribution, mainly in the southern hemisphere from Africa to India and south-east Asia, and from Australia, New Guinea, New Zealand, and the western Pacific Region to South America, where it is poorly represented. Several endemic species occur in the Juan Fernandez Islands and on St. Helena, with two species already extinct in the latter. It extends marginally beyond Africa into the western Mediterranean region of Europe, Macaronesia and Arabia, where just one or two species occur. In warm-temperate and subtropical Asia a single species of Wahlenbergia extends north to Japan and to the Bonin Islands, and has also been introduced to Hawaii. The remainder of the wahlenbergioid genera are confined either to southern Africa and Madagascar or the Mascarene Islands. In South Africa this genus comprises annuals, perennial herbs, and shrubby types, most of the latter occurring in the fynbos of the Cape region.

The Australian Wahlenbergia species are mostly annual or perennial herbs, although a few are partially shrubby at their stem bases. Although widely distributed in all states, the majority of species and the greatest diversity occurs in the south-eastern zone of the country (Smith 1992; Eddie and Cupido, in prep.).

All the New Zealand species are perennial herbs with either a rhizomatous or a radicate growth form. They occur throughout New Zealand, ranging from alpine to coastal habitats (Petterson 1997).

The 29 species of small shrubs, perennial herbs and two annual species that belong to the genus Prismatocarpus occur in the south-western Cape and Eastern Cape. Roella is a genus of 25 small shrubs and herbs that is found mainly in the south-western Cape, with one species extending into the Eastern Cape and KwaZulu-Natal. The genus Microcodon is found only in the south-western Cape and comprises four species, all of which are annuals. Merciera comprises six perennial species that are also restricted to the south-western Cape. In the vegetative state they look very similar to Roella

ciliata L. Craterocapsa consisting of five species of prostrate, often mat-forming perennial herbs, is the only genus in South Africa that has no members in the south-western Cape. It occurs in KwaZulu-Natal, Eastern Cape, Free State, Northern Province, and Gauteng Province (and as an outlier in the Chimanimani mountains of Zimbabwe). Siphocodon, with two 
divergent species, is restricted to the south-western Cape. They are slender, wiry perennials, one species, S. debilis Schltr., being exceptionally divaricating, often entangling both itself and other plants. Rhigiophyllum consists of one species that is found only in the south-western Cape. This rigid, erect shrublet is easily recognized by its stiff leaves, densely arranged on the stems and by the deep blue, tubular flowers that are borne in terminal heads. Like Siphocodon, Treichelia comprises two species that occur in the south-western Cape. These dwarf coarse herbs bear their flowers in dense terminal heads with long bracts in between the flowers. The two species of Theilera occur in the south-western Cape and Eastern Cape. They are erect shrublets with slender branches, cylindrical, somewhat asymmetrical corollas, and are found mainly inland.

Two additional genera found in southern Africa, Gunillaea, with two species ranging from Angola to Mozambique and on Madagascar, and the monotypic Namacodon from Namibia are not formally part of this study although morphologically interesting and of overall importance in an understanding of wahlenbergioid phylogeny as a whole.

The increasing number of molecular phylogenetic studies published over the last 10 years has allowed us to visualize an emerging picture of relationships within the Campanulaceae and to plug the gaps in our understanding of its classification. However, an unintended shortcoming of recent family-wide studies was the under-sampling of wahlenbergioid taxa across its distribution range (e.g. Eddie et al. 2003; Cosner et al. 2004; Haberle et al. 2009). Prebble et al. (2011) used a broader sampling of Wahlenbergia species to study the relationship within the genus across its main centers of radiation in the southern hemisphere, but still did not place the genus in the broader context of wahlenbergioid diversity, particularly with respect to endemic taxa in the Juan Fernandez Islands, the Mascarenes and St. Helena. Ideally a study on the wahlenbergioids should include all southern hemisphere groups.

In addition to the sampling dilemma, agreement on generic circumscriptions in the Campanulaceae remains largely unsettled. Typically, genera are erected when novel plants that do not fit comfortably into existing genera are discovered, or as segregates from larger genera. In the latter category, the most noteworthy examples from South African wahlenbergioids are Theilera, Microcodon and Craterocapsa p.p. from Wahlenbergia, Treichelia from Microcodon and Merciera from Trachelium and Roella. Due to the removal of small genera, the monophyly of the larger genera such as Wahlenbergia is questionable.

The criteria used to establish segregate genera are not always explicit. In the Campanulaceae, genera have often been proposed because of the exaggerated importance attached to a single character, and maintained because of tradition (McVaugh 1945). Many genera are also recognized by their possession of a suite of characters, none of which is unique to the genus in question.

The diversity in capsule structure and particularly the mode of dehiscence has been used to separate genera in the Campanulaceae (Hilliard and Burtt 1973; Thulin 1975). This 
character is not always homogeneous within the existing South African genera. In all species of Wahlenbergia, except $W$. acaulis E. Mey. and $W$. suffruticosa Cupido, the capsule characteristically dehisces by erect apical valves, which are formed by the domeshaped epigynous disc. In $W$. acaulis dehiscence takes place via protruding intercalyx folds, while $W$. suffruticosa has also departed from the typical Wahlenbergia pattern by evolving a unique mode of dehiscence in which slits develop between the depressed apical valves and extend longitudinally, separating the capsule into five segments (Cupido 2011). Hilliard and Burtt (1973) showed that not all capsules of Roella species dehisce by an apical hole as stated by Adamson (1952); in a few species the dehiscence takes place by vertical splits, which are more characteristic of Prismatocarpus.

Prismatocarpus schinzianus Markgraf was transferred to a new genus Namacodon (Thulin 1974) because it differs from Prismatocarpus in its unique mode of septicidal dehiscence, 3-locular ovary and pollen grains released in tetrads. Similarly, Thulin erected the genus Gunillaea for certain former species of Prismatocarpus and Wahlenbergia which have indehiscent capsules that open slowly by irregular decomposition of the pericarp and have hair-like projections on the testa.

The genus Theilera is questionably distinct from Wahlenbergia (Thulin 1975), mainly differing in its long cylindrical corolla tube. Marloth (1932) reported that the capsules dehisce by an apical orifice, whereas Thulin reported it as opening by apical valves as in Wahlenbergia. Phillips (1927), who erected Theilera, gave no reasons for doing so. He may have attached great importance to the cylindrical corolla tube and its possession of fascicled leaves, which would be unique in the species of Wahlenbergia from which it was segregated. The case of Treichelia is similar. Schö nland (1889) stated that the capsule dehisces by a lid. In contrast, Adamson (1950) stated incorrectly that the dehiscence takes place by slits between the ribs of the capsule. With both of these genera we can see how genera may be perceived as distinct (their overall gestalt) through suites of characters.

Craterocapsa (Hilliard and Burtt 1973) was erected to accommodate species of Wahlenbergia and Roella in which the capsule dehisces via an apical operculum. With the exception of Craterocapsa insizwae, the ovary is consistently 3-locular. C. insizwae now includes the 2-locular Roella insizwae Zahlbruckner (considered a doubtful species by Adamson (1952) due to the unavailability of sufficient study material), and the 3-locular Wahlenbergia ovalis v. Brehm. The inclusion of $W$. ovalis in Craterocapsa was done with 'only slight doubt' (Hilliard and Burtt 1973).

Apart from a few studies that could be described as merely incidental, for example Phillips's (1927) treatment of Theilera, no study has ever attempted to re-assess generic circumscriptions in South African Campanulaceae. Schö nland's review, which is more than 100 years old, remains the standard reference for the family in the region. More study material is currently available for the family and more localities known, albeit in a time of massive habitat destruction. Lowland species, some of which have high horticultural potential, are particularly under threat of extinction even before their biology is adequately understood.

\section{http://repository.uwc.ac.za}


A convincing and robust generic framework for the wahlenbergioids is crucial to resolve the numerous alpha taxonomic problems that exist in the family as well as for making informed conservation decisions.

In this study we used a broad sample of wahlenbergioid genera to address the following questions: 1. With increased sampling are the wahlenbergioids monophyletic? 2. Are the current generic circumscriptions credible and what are the options for generic revision based on this phylogeny? 3. What are the relationships between taxa from the two largest centers of wahlenbergioid diversity (South Africa and Australasia)?

\section{Materials and Methods}

Taxon Sampling-Taxa were selected to include at least one representative from each South African wahlenbergioid genus, to maximize morphological and geographical diversity, and to sample all growth forms in South Africa. Our study does not include Wahlenbergia samples from the Mascarene Islands, Juan Fernandez, and St. Helena. Although this is largely outside the scope of this paper we acknowledge these limitations and will address them in a future study. In the case of monotypic genera, only one sample was used. All species of genera with two or three species were investigated. In genera comprising more than three species, at least one species from each currently recognized infra-generic group was included in the study. For example, in the case of Roella one species per series and for Prismatocarpus one species per series of each subgenus was sampled. The South African specimens were identified as far as possible to species with the aid of the most recent generic treatments, and the collections housed in BOL, NBG, PRE and SAM (abbreviations as in Holmgren et al. 1990). In cases where specimens could not be named with confidence, they were identified to genera. The unnamed specimens do not necessarily represent undescribed taxa but rather ambiguity in the current taxonomy. The New Zealand and Australian samples are a subset of the endemic rhizomatous and radicate species included in Prebble et al. (2011).

The ingroup comprises DNA sequences from the chloroplast $\operatorname{trn} L-F$ and nuclear ribosomal ITS regions obtained from 96 and 87 taxa, respectively (Appendix 1). Of these 89 are South African, six New Zealand Wahlenbergia, seven Australian Wahlenbergia, one European Wahlenbergia and one mainly tropical and northern African Wahlenbergia samples. Every attempt was made to have the same number of taxa for each gene region, but for some taxa it was impossible to obtain ITS sequences. All taxa were field collected and DNA was isolated from silica dried or fresh leaf material. In taxa with reduced leaves such as Siphocodon spartioides and Wahlenbergia virgata, the stem epidermis was also used in the isolation to ensure that a sufficient amount of isolated DNA was obtained.

Outgroup taxa were selected from the mainly East Asian platy-codonoids, the predominantly northern hemisphere campanuloids (Eddie et al. 2003) and the closely related families of Lobeliaceae and Cyphiaceae (Cronquist 1981; Lammers 1992; Gustafsson and Bremer 1995; APG 2003; Cosner et al. 2004). 
DNA Extraction, Amplification and Sequencing-Extractions for all samples followed a modified CTAB method (Doyle and Doyle $(1987,1990)$ outlined in detail in Prebble et al. (2011). Amplification of the nuclear ribosomal ITS region was conducted using primers $\mathrm{AB} 101 \mathrm{~F}$ and $\mathrm{AB102R}$ (Baldwin 1992) for the South African samples, whereas the Australasian samples were amplified using primers ITS5 and ITS28cc (Wagstaff and Garnock-Jones 1998). The chloroplast region was amplified for all samples using trnL-Ff and $\operatorname{trnL}-F c$ (Taberlet et al. 1991). Where amplification of the ' $\mathrm{c}$ ' to ' $\mathrm{f}$ ' region failed, internal primers ' $d$ ' and 'e' (Taberlet et al. 1991) were used in conjunction with 'c' and ' $f$ ' to amplify the gene in two non-overlapping segments.

In South Africa sequencing of the PCR products was performed for 26 cycles in a GeneAmpÒ PCR System 9700 using the ABI PRISM Dye terminator cycle sequencing ready reaction kit (Applied Biosystems, Foster City, California). Each cycle consisted of $96^{\circ} \mathrm{C}$ denaturation for $10 \mathrm{sec}, 50^{\circ} \mathrm{C}$ annealing for five seconds and $60^{\circ} \mathrm{C}$ extension for four minutes. The same primers were used as for the original PCR. The samples were resolved on polyacrylamide electrophoresis gels on an Applied Biosystems 377 automated DNA sequencer. For each taxon the complementary strands were assembled and edited using Sequencher 4.1 (Gene Codes Inc., Ann Arbor, Michigan).

In New Zealand the PCR products were sequenced on an ABI3730 Genetic Analyzer by the Allan Wilson Centre Genome Service (Massey University, Palmerston North, New Zealand). Reverse compliments were sequenced to confirm the reads for a number of samples.

Sequence Alignment-Sequences were aligned by eye. Gaps that resulted from the alignment of unequal sequences were coded as missing data and not scored for inclusion in the analyses. ITS sequences proved difficult to align and the program MEGA version 3.1 (Kumar et al. 2004) was used to provide an initial alignment.

Sequences were aligned independently using a consistent alignment convention of moving characters to the left if alternate alignments were possible. Regions in the matrices that were difficult to align unambiguously were excluded.

Combined trnL-F and ITS Data Set-The data was concatenated following Nixon and Carpenter (1996). The concatenated molecular data set of 92 taxa consisted of 83 ingroup and 10 outgroup taxa. Only taxa common to both the individual data sets were used in the combined analysis.

Phylogenetic Analyses-The data matrices for each of the two gene regions were analyzed separately and as a combined data matrix using parsimony and Bayesian Inference. Parsimony analyses were performed using PAUP* $4.0 b 10$ (Swofford 2003) with all characters weighted equally (Fitch parsimony; Fitch 1971). One thousand heuristic replicated searches were performed using random stepwise taxon addition with branch-swapping by treebisection reconnection (TBR), saving five trees per replicate. Support for each clade was assessed by bootstrap analysis (Felsenstein 1985), using 1000 simple taxon addition 
replicates and TBR branch-swapping. Bootstrap values were interpreted as weak (50-74\%), moderate (75-89\%) and strong (90-100\%).

Consistency (CI) (Kluge and Farris 1969) and retention (RI) (Farris 1989) indices were calculated for each. For Bayesian analyses models of molecular evolution that best the data were determined in Modeltest (version 3.06; Posada and Crandall 1998) using the Akaike information criterion (Akaike 1974) for each of these data sets. For the combined analysis, parameters applying to more than one partition were unlinked to allow values to differ among partitions. One million generations were run with four independent chains (Markov chain Monte Carlo) and were sampled every hundred generations, resulting in an overall sampling of 10,000 trees.

The Bayesian analyses were conducted using MrBayes 3.1 (Huelsenbeck and Ronquist 2001) applying the substitution models listed in Table 1. Stationarity was established visually by plotting the negative log-likelihood (-LnL) values against generation time in Microsoft Excel to determine the burn-in period. For the first Bayesian analysis, stationarity was reached after 17,400 , for the second after 59,300, and for the third after 76,200 generations of trees. All trees were transferred to PAUP* and trees visited prior to stationarity were discarded. The remaining trees were used to generate a 50\% majority-rule consensus tree with posterior probability values (PP- values) shown above the branches. PP-values of 3 0.95 are considered evidence of significant support for a group (Miller et al. 2004).

The partition homogeneity test (Farris et al. 1995) as implemented in PAUP* 4.0b10 (Swofford 2003) was used to assess topological congruence between the trnL-F and ITS data sets. One hundred partition homogeneity replicates were used with 100 replicates of random addition sequence, TBR branch swapping, saving 10 trees per replicate.

TABLE 1. Statistics for DNA sequence regions used in the phylogenetic analysis.

\begin{tabular}{|c|c|c|c|}
\hline & $t m L-F$ & ITS & Combined \\
\hline \multicolumn{4}{|l|}{ Characters } \\
\hline Number included & 882 & 529 & 1,411 \\
\hline Parsimony-informative & $297(34 \%)$ & $289(55 \%)$ & $553(39 \%)$ \\
\hline $\begin{array}{l}\text { Variable, parsimony- } \\
\text { uninformative }\end{array}$ & $173(20 \%)$ & $99(19 \%)$ & $274(19 \%)$ \\
\hline Constant & 412 & 141 & 584 \\
\hline \multicolumn{4}{|l|}{ Phylogenetic Analyses } \\
\hline Number of Trees & 334 & 212 & 8 \\
\hline Tree length & 1,020 & 1,493 & 2,371 \\
\hline Consistency Index & 0.679 & 0.494 & 0.568 \\
\hline Retention Index & 0.868 & 0.750 & 0.782 \\
\hline $\begin{array}{r}\text { Model of DNA } \\
\text { substitution }\end{array}$ & $\mathrm{TVM}+\mathrm{G}$ & $\mathrm{GTR}+\mathrm{I}+\mathrm{G}$ & $\begin{array}{c}\text { Separate models for } \\
\text { each partition }\end{array}$ \\
\hline
\end{tabular}

\section{Results}

The characteristics of the sequences for each analysis performed are summarized in Table 1. 
Combined trnL-F and ITS Analysis-The 50\% majority rule consensus tree inferred from the Bayesian analysis (Fig. 1) resolved similar clades as the maximum parsimony analysis, but is better resolved and supported.

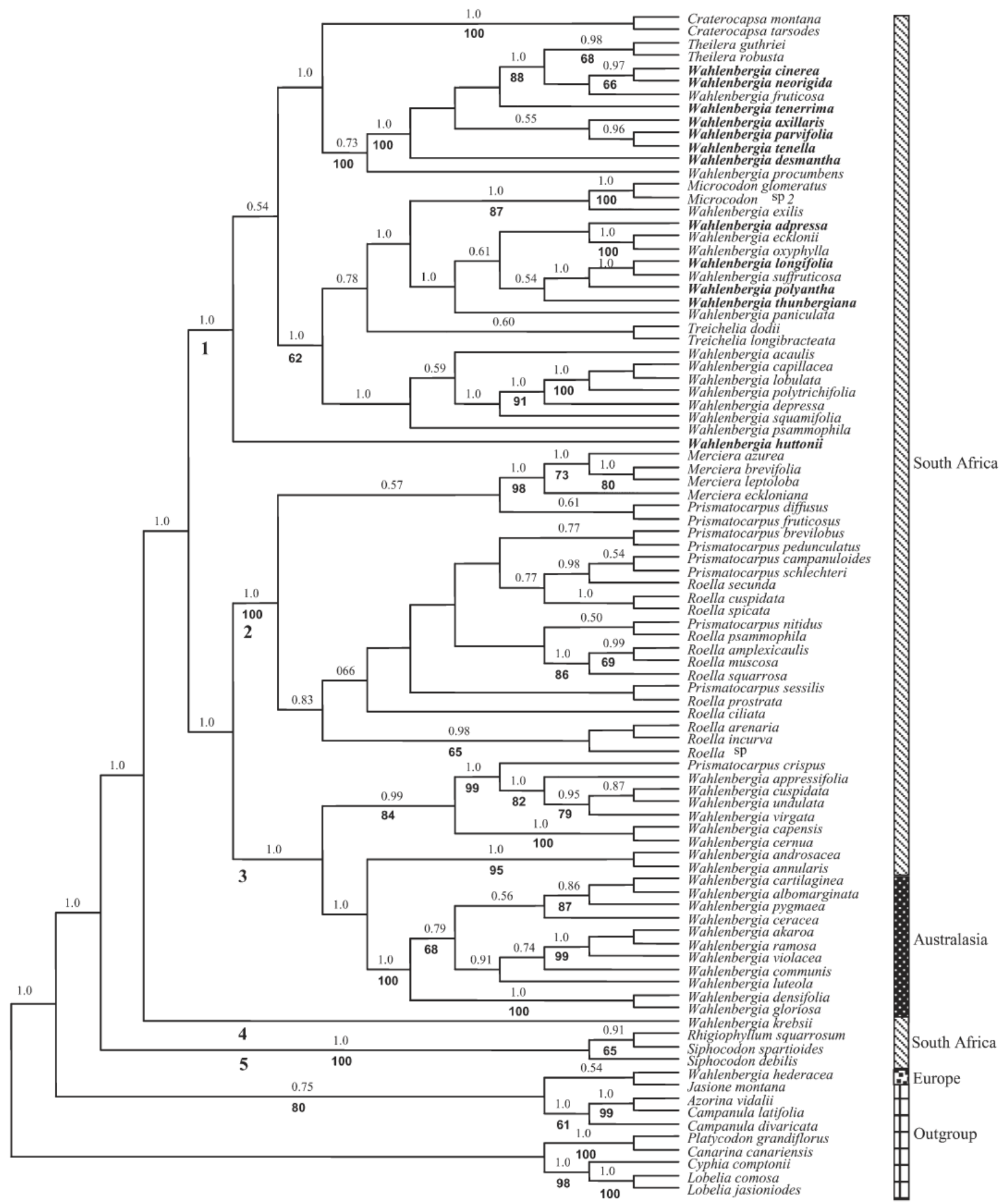

FIG. 1. Bayesian $50 \%$ majority rule consensus tree obtained for the combined trnL-F and ITS datasets for southern African and Australasian wahlenbergioids and outgroup. Taxa previously classified in Lightfootia nom. illeg. are in bold. Numbers above branches indicate Bayesian posterior probability (PP) values; numbers below indicate Parsimony bootstrap (BS) values. Geographic distribution of taxa is indicated in the right margin and the major clades are labeled. 
The ingroup is split into two main groups, supported by a posterior probability (PP) value of 1.o. The first included the single species of Rhigiophyllum and the two species of Siphocodon and is well supported with a posterior probability (PP) value of 1.o. The second of the two groups includes all remaining samples, comprising representatives of eight genera. 


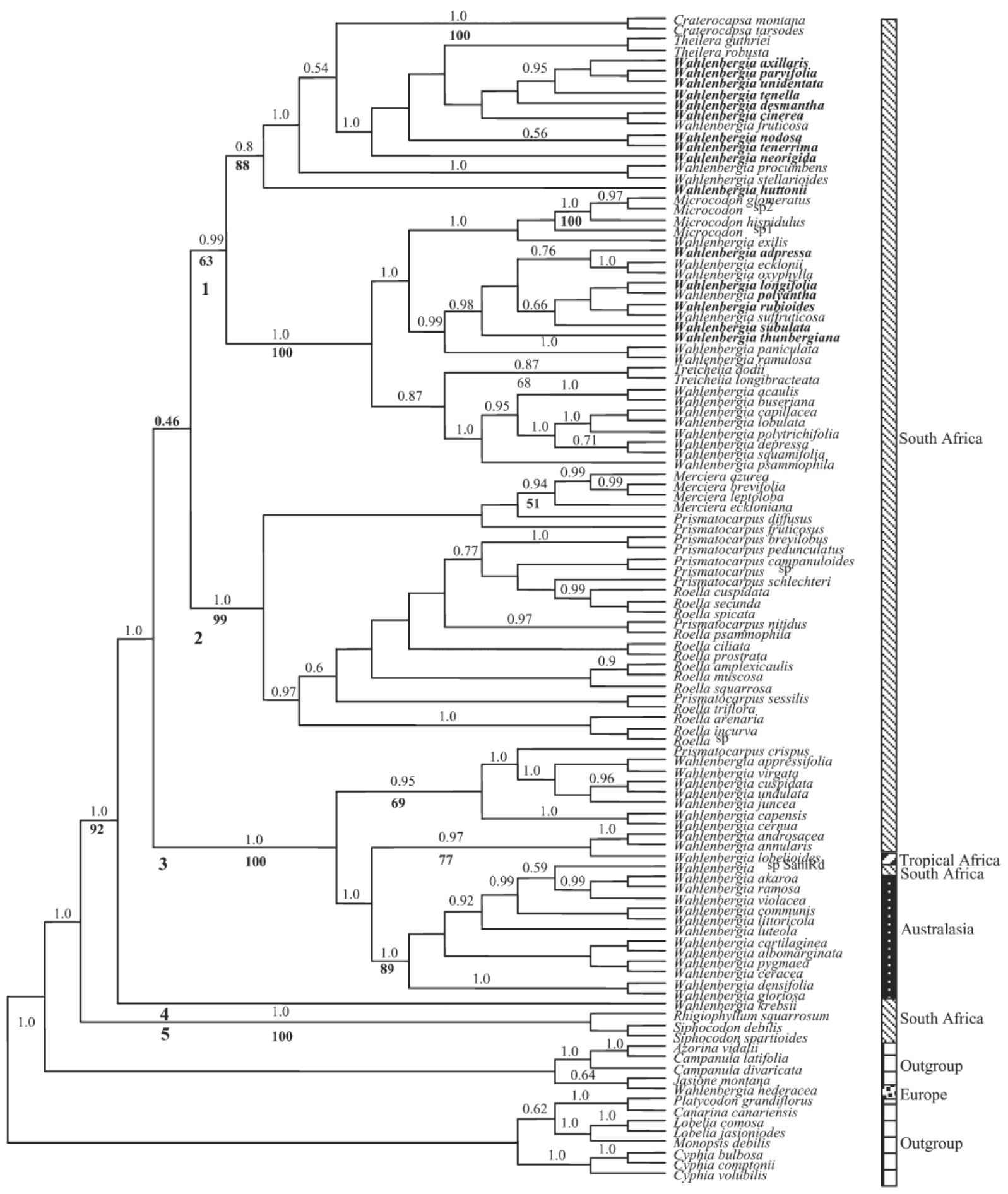

Fig. 2. Bayesian $50 \%$ majority rule consensus tree obtained from the trnL-F dataset for southern African and Australasian wahlenbergioids and outgroup. Taxa previously classified in Lightfootia nom. illeg. are in bold. Numbers above branches indicate Bayesian posterior probability (PP) values; numbers below indicate Parsimony bootstrap (BS) values. The major clades are labeled, as are the geographic distribution of taxa. 


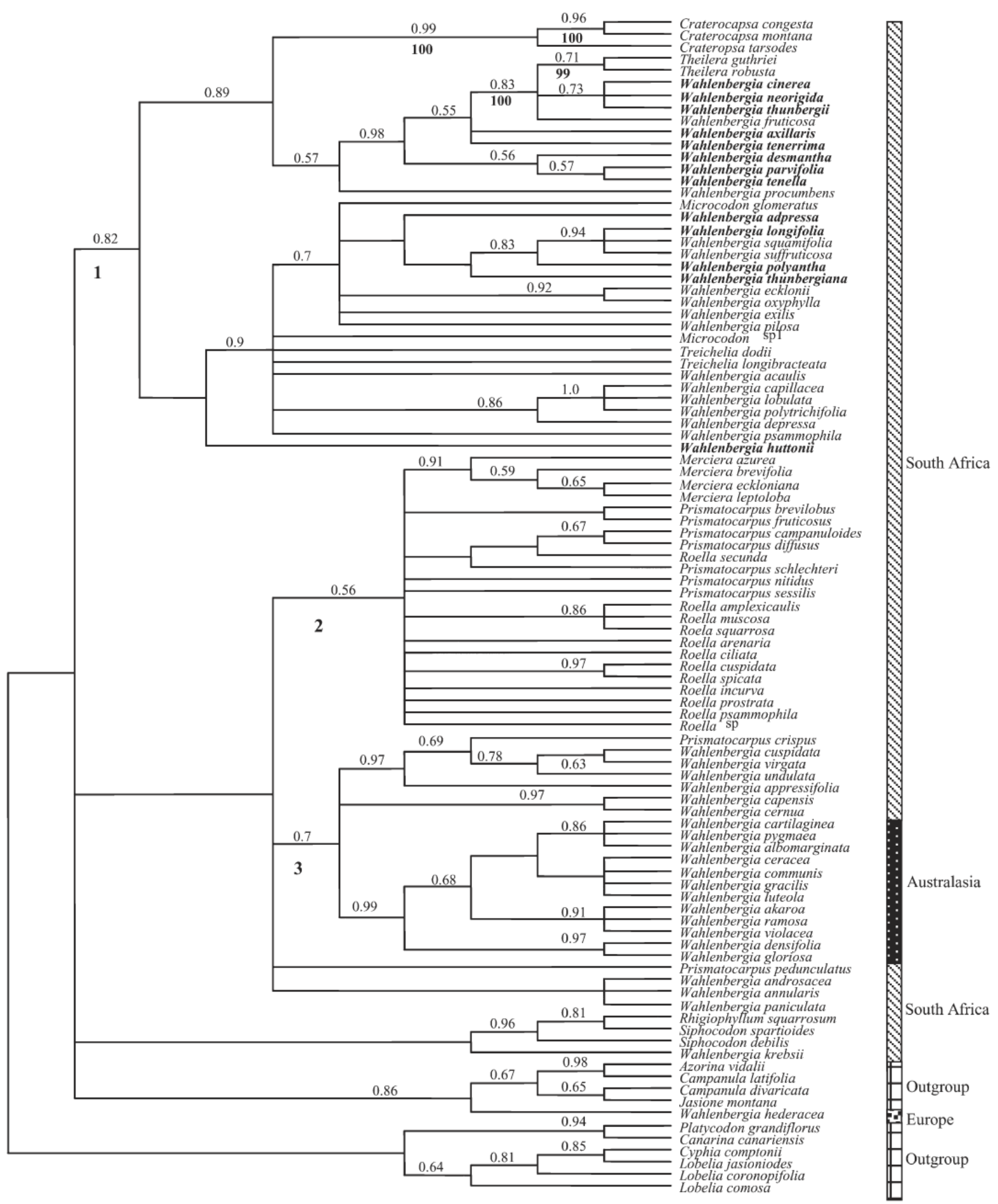

FIG. 3. Strict consensus tree for the maximum parsimony analysis for the ITS data set for southern African and Australasian wahlenbergioids and outgroup. Taxa previously classified in Lightfootia nom. illeg. are in bold. Numbers above branches indicate Bayesian posterior probability (PP) values; numbers below indicate Parsimony bootstrap (BS) values. The major clades are labeled, as are the geographic distribution of taxa.

Wahlenbergia krebsii is sister to the rest of the species in this group. The remainder is resolved into three clades (1, 2, and 3), among which the relationships are strongly supported. The largest of the three clades, 1 , is strongly supported $(\mathrm{PP}=1.0)$ and resolved into two subclades sister to $W$. huttonii. The first subclade is strongly supported

\section{http://repository.uwc.ac.za}


$(\mathrm{PP}=1.0)$ and includes species of Wahlenbergia, Theilera and Craterocapsa. The Craterocapsa species formed a clade with $\mathrm{PP}=1.0$, while the Theilera species formed a clade with Wahlenbergia species most of which were previously classified in the genus Lightfootia nom. illeg. The second subclade has a PP value of 1.0, and comprises species of Wahlenbergia, Microcodon and Treichelia. The genus Treichelia is weakly supported (PP = o.60), while the two species of Microcodon form a strongly supported ( $\mathrm{PP}=1.0$ ) clade. The position of Wahlenbergia in Clades 1 and 3 renders this genus paraphyletic.

Clade 2 is strongly supported ( $\mathrm{PP}=1.0$ ) and is formed by species of Roella, Prismatocarpus (except P. crispus in clade 3) and Merciera. The four species of Merciera resolve as monophyletic $(\mathrm{PP}=1.0)$ and are sister to two Prismatocarpus species in a weakly supported ( $\mathrm{PP}=$ 0.57) subclade. The remainder of the Prismatocarpus species are interspersed among the Roella species in a moderately supported $(\mathrm{PP}=0.83)$ subclade.

Clade 3 is strongly supported ( $\mathrm{PP}=1.0$ ) and is formed by species of Wahlenbergia with Prismatocarpus crispus. This clade comprises three subclades. The first group of annuals and perennial herbs which include $P$. crispus is supported by a PP value of 0.99. The second comprise the South African, $W$. annularis and the tropical and southern Africa $W$. androsacea annual species, supported by a PP value of 1.0, and the third is a strongly supported group $(\mathrm{PP}=1.0)$ of Australasian Wahlenbergia.

The topology of this combined 50\% majority rule consensus tree shows a high degree of congruence with the consensus trees of the separate trnL-F data set (Fig. 2). As in the trnL$F$ analysis Wahlenbergia krebsii appears isolated and is placed sister to the large clade that excludes Rhigiophyllum and Siphocodon. W. huttonii, which resolved as sister to the Craterocapsa-Theilera-Wahlenbergia subclade in the trnL-F analysis, resolves as sister to the entire clade A as in the ITS analysis (Fig. 3). The Craterocapsa-Theilera-WahlenbergiaMicrocodon-Theilera clade, the Roella-Prismatocarpus-Merciera clade, the clade involving the Australasian Wahlenbergia as well as the placement of $W$. hederacea among the outgroup taxa are common in all analyses.

Data Combinability-The partition homogeneity test found that the trnL-F and ITS data sets were significantly incongruent $(p=0.01)$. However, a number of studies have shown that the results of the ILD test can be misleading (Wiens 1998; Dolphin et al. 2000; Reeves et al. 2001; Yoder et al. 2001; Ram'irez 2006). Therefore, the data sets were nonetheless combined in a total evidence approach (Kluge 1989) because of the possibility of resolving more clades, reducing the number of parsimonious trees and obtaining better supported clades.

A comparison of the trees obtained for the separate $\operatorname{trnL}-F$ and ITS analyses suggest a general congruence in topology. The areas of conflict involve the placement of species such as Lobelia comosa, L, coronopifolia, L. jasionoides, Cyphia comptonii, W. huttonii, W. krebsii and $P$. pedunculatus, which are nested in poorly supported clades. 


\section{Discussion}

Monophyly of the Wahlenbergioid Group-Our results support previous molecular studies using ITS sequences (Eddie et al. 2003) and combined atpB, matK and rbcL (Haberle et al. 2009) that have shown that for the wahlenbergioids to be monophyletic, $W$. hederacea has to be excluded. Recent molecular studies on Wahlenbergia (Prebble et al. 2011) confirmed the distant relationship between $W$. hederacea and its congeners. This species is somewhat intermediate in morphology between typically wahlenbergioid and typically campanuloid taxa, and has an unusual geographical distribution (Lusitanian) on the western seaboard of temperate Europe. In its mode of capsule dehiscence it resembles the wahlenbergioids but its overall vegetative morphology is similar to the isophylloid species of Campanula (Eddie and Cupido, 2013, in review). Furthermore, the molecular results for $W$. hederacea (ITS, matK, atpB, $r b c L$, and $t r n L-F$ ) are not equivocal. It obviously is not closely related to the wahlenbergioid genera of the southern hemisphere sampled in this and previous studies but possibly to other northern-hemisphere genera such as Jasione and Feeria although it does not bear a close resemblance to either. Jasione was also traditionally placed within the wahlenbergioids but studies of rearrangements of the chloroplast genome (Cosner et al. 2004) have shown that, from a molecular point of view, it is best treated as campanuloid. Subsequent studies suggest that $W$. hederacea should also be placed among the campanuloids (Eddie et al. 2003; Haberle et al. 2009).

The taxonomic history of $W$. hederacea indicates its uncertain position in classifications. It has been treated as belonging to a separate genus, e.g. Schultesia Roth (nom. illeg.), Aikinia Salisb. ex Fourr. (nom. illeg.) and even Roucela (Dumort). Eddie et al. (2003) referred to $W$. hederacea, Jasione and other taxa such as Musschia Dumort. in an unresolved clade as transitional (i.e. ambiguous in an evolutionary sense) between the wahlenbergioids and campanuloids. When Eddie (in Eddie et al. 2003) introduced the term 'wahlenbergioid', referring to the possible affinities and appearance of a taxon, he applied it principally and most appropriately to the southern hemisphere group with porate pollen, comprising about 15 genera. At the same time it was recognized that taxa with 'wahlenbergioid' characteristics also occurred in Europe, e.g.: 'Wahlenbergia' hederacea; Edraianthus A. DC.; Jasione L.); the Mediterranean region (Feeria Buser, Jasione); North America (Githopsis Nutt.); and south-east Asia (Peracarpa Hook. f. \& Thomson). Similarly, within southern Africa there are formal members of the Wahlenbergioideae that have campanuloid characteristics, e.g. Prismatocarpus, Namacodon and some species of Wahlenbergia, e.g. W. campanuloides (Delile) Vatke. Within the southern hemisphere, the highest generic and species diversity of wahlenbergioids is found in southern Africa. This region also contains 12 endemic genera and is clearly the current center of maximum wahlenbergioid divergence. This diversification is probably the result of intense selection pressures present in the very diverse South African environments in addition to long periods of isolation (Cupido 2009).

The topologies discovered by the trnL-F and combined datasets suggest, as inferred by Eddie et al. (2003) for ITS, that the wahlenbergioids and campanuloids shared a common ancestor. The splitting of the two lineages correlates with a vicariance interpretation of the 
respective groups, with the campanuloids predominantly inhabiting the northern hemisphere and the wahlenbergioids inhabiting the southern hemisphere.

The presence of campanuloid and wahlenbergioid species in tropical Africa suggest that this region can be seen as a zone of overlap that was formed by north- and southward migration of species. This overlap may not have been present in the early history of the family; it is highly likely that the $2 n=28$ group of Campanula, which is now highly relictual in central Sahara, Cape Verde Islands and eastern Afica, spread into sub-Saharan Africa in mid-Tertiary times reaching as far south as Tanzania (Eddie and Cupido in prep.). The equivalent northward migration of wahlenbergioids resulted in the presence of species such as Wahlenbergia lobelioides in the Mediterranean and Macaronesia, merely fringing on Europe proper. These relatively late migrations must not be confused with the presence of Eddie's 'transitional' taxa such as Feeria and Jasione which, on the basis of their geographic distribution and their position on molecular topologies, appear to be much more ancient and relictual in the Mediterranean region (Eddie et al. 2003; Eddie and Cupido in prep.).

A southward migration of tropical African species into the Cape flora as first suggested by Levyns (1964) was probably influenced by the development of high volcanic mountains in Ethiopia and East Africa during the Tertiary (Axelrod and Raven 1978) accompanied by global climatic changes (Kennet 1980), such as the glaciation of Antarctica, a drop in the sea levels, and the start of a dry cold phase (Zachos et al. 2001). It is assumed that these conditions formed the setting for the ancestral wahlenbergioid elements that by way of adaptive responses to the changes in climate and topography triggered their subsequent diversification in southern Africa. Monophyly of South African and Australasian Wahlenbergioid Genera-Evidence from all analyses suggests that neither samples from South African, Australian nor New Zealand group to form discrete clades. The New Zealand species form two clades nested within the Australian species, and the Australian and New Zealand species form a strongly supported monophyletic sister group to one of the South African clades. Although, the study of Harberle et al. (2009) lacked South African Wahlenbergia and Treichelia samples and included only a single Australian sample, they also found Wahlenbergia and Prismatocarpus to be not monophyletic. Generic Limits-The molecular data do not support all the current generic circumscriptions in the family, six smaller genera are recovered as monophyletic (i.e. Craterocapsa, Theilera, Microcodon, Treichelia, and Merciera and Siphocodon) but Wahlenbergia, Prismatocarpus and Roella are non-monophyletic. The monophyly of Rhigiophylum is unclear as only a single individual was included in our study. Five species assemblages become apparent, corresponding to clades 1-5 on Fig. 1: 1. Wahlenbergia-Theilera-Microcodon-CraterocapsaTreichelia, 2. Roella-Prismatocarpus-Merciera, 3. Wahlenbergia-P. crispus, 4. Wahlenbergia krebsii, 5. Rhigiophyllum-Siphocodon.

\section{WAHLENBERGIA-THEILERA-MICROCODON-CRATEROCAPSA-TREICHELIA-} Wahlenbergia is not monophyletic, with Theilera, Craterocapsa, Microcodon and Treichelia all nested within it. These genera are part of the wahlenbergioid line of diversification, and each of them has probably adapted to unique ecological conditions such as

\section{http://repository.uwc.ac.za}


fire, rainfall and soil type. It is assumed that the summer-dry climate increased the frequency of fire that ultimately became an important ecological factor, particularly in the Cape Floristic Region. These climatic and topographical changes provided diverse habitats, each with its unique set of selective pressures on the species that occupy them (Cupido 2009). Most of the Wahlenbergia species adapted to the summer-dry conditions and fire by developing or perhaps retaining an ancestral shrubby habit that allows them to die back and resprout. Treichelia and Microcodon have adapted to the same dry conditions as spring flowering annuals that survive the harsh summer as seed, whereas Craterocapsa and Theilera occupy areas where these conditions are mostly absent.

Previous authors separated these genera from Wahlenbergia because of the importance placed on differences in the mode of capsule dehiscence or floral morphology. However, Theilera and Microcodon share the same mode of capsule dehiscence with Wahlenbergia. Theilera was separated from Wahlenbergia on a suite of characters, including its tubular corolla and fascicles of leaves. The corolla is slightly curved, almost zygomorphic and both anthers and stigmatic lobes are unusual. The genus is also restricted to the drier montane areas from the Swartberg near Oudtshoorn, to Willowmore where the rainfall is mainly in summer and fire absent. In Microcodon, the locules alternate with the calyx lobes instead of being opposite to them, as in the case of Wahlenbergia species with a five locular ovary.

The close relationship between Craterocapsa and Wahlenbergia is interesting since two of the four species of Craterocapsa were originally described as either Wahlenbergia or Roella. Thulin (1975) suggested a close relationship between Craterocapsa and Roella based on the resemblance in capsule dehiscence, which takes place by an apical operculum. This suggestion is surprising because Roella comprises mostly shrublets (except $R$. muscosa, $R$. uncinata, $R$. recurvata and $R$. goodiana which are herbaceous) and Craterocapsa herbs. In addition Roella occurs mainly in the south-western Cape (except $R$. glomerata which extends into the Eastern Cape and KwaZulu Natal) while Craterocapsa occurs only in the Eastern Cape, KwaZulu Natal and Zimbabwe. Craterocapsa insizwae (separated from Roella) was not sampled for this study. Craterocapsa and Roella are not found in similar positions on our tree (Fig. 1). Although the molecular data suggest that Treichelia, Microcodon, Theilera, and Craterocapsa are most probably congeneric with Wahlenbergia it does however support them as coherent separate groups within a larger Wahlenbergia, which is corroborated by the morphology and ecology of the plants.

The original concept of Lightfootia as a distinct genus from Wahlenbergia is not supported by these data, giving some support to Thulin's (1975) union of the two or at least some species of Lightfootia with Wahlenbergia. However, it is partially supported by the fact that some of the shrubby species formerly treated as Lightfootia do cluster together and are recognizably distinct. It was separated mainly on the basis of corolla structure, style length and habit. All these characters overlap between the two genera and are not useful for generic distinction on their own. Despite its shrubby habit, several species $(W$. adpressa, $W$. axillaris, $W$. cinerea, $W$. desmantha, $W$. huttonii, $W$. longifolia, $W$. neorigida, W. nodosa, W. parvifolia, W. polyantha, W. rubioides, W. subulata, W. tenella,

\section{http://repository.uwc.ac.za}


$W$. tenerrima, W. thunbergiana, W. unidentata) previously treated as Lightfootia, are associated with herbaceous Wahlenbergia species as well as the shrubby Theilera. These data also support the view that Theilera is closely related to Wahlenbergia. Theilera is unique among wahlenbergioids in its flowers, habitat and geographical distribution.

2. ROELLA-PRISMATOCARPUS-MERCIERA-The close relationship between Roella, Prismatocarpus and Merciera, as suggested by Adamson (1952, 1955), is confirmed by the molecular data of this study and that of Cosner et al. 2004. Adamson postulated that Roella and Prismatocarpus are derived from a common ancestor and that Merciera was derived from Roella series Roella (as Ciliatae). This series comprises eight species: $R$. ciliata L., $R$. incurva Banks ex A. DC., $R$. rhodantha Adamson, $R$. maculata Adamson, $R$. triflora (R. D. Good) Adamson, $R$. dregeana A. DC., R. psammophila Schltr., $R$. dunantii A. DC. However, in our analyses the relationships of Merciera are poorly supported, though it is shown to be sister to a clade containing most species of Prismatocarpus and all species of Roella sampled for this study. This Cape floral clade, according to the definition used by Linder (2003), can be associated with the establishment of the fynbos vegetation and radiated in response to drought and fire (Linder and Hardy 2004). Merciera for example, resprouts and grows prolifically after fire, but after a long absence of fire the plants become moribund and start disappearing from the veld (Cupido 2006). Vegetatively, it is not always possible to separate Merciera from species of Roella series Roella (Cupido 2006). Adamson (1952) also stated that, without knowledge of the mode of capsule dehiscence, it is difficult to assign some species of Roella and Prismatocarpus to one genus or the other.

The extent of morphological variation within Roella and Prismatocarpus prompted Adamson (1952) to subdivide these two genera into five series and two sub-genera respectively. Subgenus Prismatocarpus is further subdivided into three series. Little support for the subgeneric classification of Adamson (1952) is evident, except that in the trnL-F topology Roella series Spicatae, is discovered with strong support $(\mathrm{P}=0.99)$, formed by $R$. cuspidata, $R$. secunda and $R$. spicata. Also $P$. diffusus, the type species of the Prismatocarpus subgenus Afrotrachelium is sister to Merciera with which it shares a narrow tubular corolla. The paraphyletic nature of these two genera casts doubt on the value of the single fruit character to indicate generic limits. Only species of Merciera formed a monophyletic group in all analyses.

2. WAHLENBERGIA-P. CRISPUS-Prismatocarpus crispus, one of two herbaceous (annual) species in Prismatocarpus is nested within a strongly supported clade comprising several South African herbaceous Wahlenbergia species. The other annual species, $P$. hildebrandtii Vatke, was not sequenced in this study because collecting efforts failed. Thulin (1974) found that this species, as treated by Adamson (1952) was heterogeneous. He then transferred all the Dinter collections from Namibia to a new genus Namacodon. The remaining specimens were the type collection from the Hatamberg (Meyer 1896) and a collection from Vanrhynsdorp (Esterhyusen 1422). The type was probably destroyed in Berlin during WWII and the other one is deposited in the Bolus Herbarium, Cape Town. Examination of this specimen strongly suggests that $P$. hildebrandtii is conspecific with $P$.

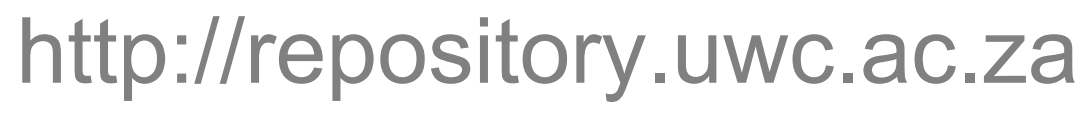


crispus. The placement of $P$. crispus is surprising, but it is similar in all analyses even after having been re-sequenced from different individuals to eliminate potential sampling errors. Apart from the herbaceous habit, $P$. crispus also shares a funnel-shaped corolla with these Wahlenbergia species. However their modes of fruit dehiscence differ: Wahlenbergia dehiscence is by apical valves, while that of $P$. crispus is by longitudinal slits that do not correspond with the calyx lobes. The relationship between $P$. crispus and Wahlenbergia requires further study.

The ancient flora of southern Africa was tropical (Linder and Hardy 2004), but when the climate became drier the tropical flora was largely decimated, leaving behind relics such as Prionium, Metrosideros, Brabejum and most likely a shrubby wahlenbergioid flora that would later occupy the fynbos. The nesting of species ( $W$. androsacea, $W$. virgata, $W$. undulata and $W$. lobelioides (trnL-F analysis only)) shared with tropical Africa in this clade corroborates the affinity between the two floras and perhaps suggests a northward migration of these species. Furthermore, the close relationship between the complex species $W$. lobelioides and $W$. androsacea, and with species in Australia as suggested by Thulin (1975) is confirmed, at least, by the trnL-F data. The argument for the affinity between African and Australian species is further supported by the association of the unidentified South African species, W. sp (Sani Rd) with the Australasian species. It is possible that this species is related to the mainly Asian $W$. marginata complex which is no longer recognized in mainland Australia. It is recorded from New Guinea but may be easily confused with other similar species (Smith 1992; Petterson 1997; Lammers 2007). The possibility that the unidentified taxon was introduced to South Africa is not excluded as suggested by Prebble et al. (2011) and will be discussed in a separate article.

The monophyletic relationship of the Australasian Wahlenbergia (plus the unidentified $W$. sp (Sani Rd) was also recovered in Prebble et al. (2011). The species affinities within this clade also match previously identified groups e.g. $W$. cartilaginea, $W$. pygmaea and $W$. albomarginata are all species with the rhizomatous growth form endemic to New Zealand. The relationships within the Australasian Wahlenbergia are discussed further in Prebble et al. (2012).

4. WAHLENBERGIA KREBSII-The isolated position of $W$. krebsii needs further investigation. Thulin (1975) placed this species with $W$. pusilla in a group based on unique seed morphological features, but never doubted its wahlenbergioid nature. It is a variable species that Thulin (1975) subdivided into two subspecies. W. krebsii subspecies krebsii is southern African, occurring in Lesotho and all the South African provinces except the Western and Northern Cape. The other subspecies, $W$. krebsii subspecies arguta is found throughout tropical Africa. Because sampling errors were initially suspected this species was re-sequenced for the trnL-F data matrix, but its position on the tree topology remained unchanged. In the case of the North American Campanulaceae seed morphology proved helpful in revealing recognizable generic patterns (Shetler and Morin 1986). In a recent seed coat study for the South African taxa Cupido et al. (2011) described the seed coat pattern of

\section{http://repository.uwc.ac.za}


$W$. krebsii as distinctly reticulate with keeled and verrucate radial walls, which was unique among the species sampled. However, it remains unclear whether this species could be the type for the formation of a new genus.

5. RHIGIOPHYLLUM-SIPHOCODON-The most obvious morphological similarity between these two genera is their epipetalous stamens. Both genera are limited to the south-eastern parts of the Western Cape. Rhigiophyllum is endemic to the NapierBredasdorp area whereas Siphocodon occurs from Sir Lowry's Pass to Riviersonderend. Adamson (1955) suggested that Rhigiophyllum was derived from Roella series Squarrosae ( $R$. amplexicaulis Wolley-Dod, $R$. decurrens L'Hé r., $R$. squarrosa P. J. Bergius) possibly because of leaf structure and arrangement. Rhigiophyllum has the same tubular corolla structure as Merciera, Theilera and P. diffusus but none of these taxa was considered as a possible ancestral stock of Rhigiophyllum by him. The molecular results together with the unique pollen morphology in Rhigiophyllum and Siphocodon have allowed us recognize the distinctiveness of these genera and to place them in a separate tribe, the Rhigiophylleae Eddie \& Cupido (Eddie et al. 2010). Rhigiophyllum and S. spartioides form a sister relationship in the ITS tree. In addition to the previously mentioned characters, these two species have the same seed morphology and number of locules. However, other than similarity in these mostly inconspicuous characters, they are morphologically distinct.

Implications for a Reclassification-For most of the 20th century, the classification of southern African wahlenbergioids has served well enough from an end-users perspective. With the publication of additional genera the classification still remained stable and workable. However, with the advent of molecular and cladistic techniques, the search for phylogenetic relations among the various taxa has shown that the situation is far from clearcut. The molecular evidence of how evolution has proceeded within the group presented here is clearly in some disagreement with the current classification in the family based on morphological criteria, and raises issues regarding generic classification.

In order to translate the results of this study into a generic classification based on the principle of monophyly, following for example the guidelines proposed by Backlund and Bremer (1998) of maximum stability, phylogenetic information, support for monophyly, and ease of identification, there are three main options. Option 1 is to recognize all in-group taxa as a single enlarged genus with the possibility of mono-phyletic lineages at subgeneric level. This would mean merging clades $1,2,3,4$, and 5 into a single genus, for which the oldest valid name, without conservation of Wahlenbergia, is Roella. Option 2 is to recognize two genera with the possibility of monophyletic lineages at subgeneric level. This would be achieved by merging clades 1, 2, 3, and 4 into a single large genus for which the earliest valid name would be Roella. The second genus corresponds to clade 5 for which the earliest available name is Rhigiophyllum. These two genera would be distinguishable from each other by the difference in stamen fusion which is free in clades 1-4 and epipetalous in clade 5 . Option 3 is to recognize the clades $1,2,3,4$, and 5 , or reciprocally monophyletic groups within these clades, at the genus level. However, no morphological characters are currently

\section{http://repository.uwc.ac.za}


known with which to base genera comprising clade 1, 2 or 3 on - i.e. there are no known morphological synapomorphies for these clades, which makes this option undesirable at present. A similar situation in Veronica has been resolved recently by collapsing the nested genera into an enlarged Veronica (Albach et al. 2004; Garnock-Jones et al. 2007) (as in Option 2) but that has not been without controversy (Brummitt 2006; Gardner 2007; Garnock-Jones and Albach 2008).

This is a divisive issue in taxonomy today, and it is difficult to reconcile (A) the preference to see classifications based on monophyletic groups, as the best way to make taxonomy a falsifiable and therefore science based field, and as a method for generating a stable classification scheme that reflects evolution; with (B) the desirability of using morphological criteria based on recognition of gestalt (i.e. the totality of appearance through suites of characters) as the basis for a workable classification that is both expedient and generally reflective of phylogenetic relations. This study has shown that a small number of taxa present considerable ambiguity in their placement, for example Prismatocarpus crispus, $P$. pedunculatus, Wahlenbergia krebsii, W. acaulis, $W$. suffruticosa, and $W$. hederacea, and it is to these problems that future taxonomic research should be addressed.

At this stage, we recommend that only minor adjustments are appropriate for the classification of South African wahlenbergioids. This allows us to recognize the evolutionary uniqueness (ecological and/or morphological) of taxa without losing sight of their context in phylogeny. In a forthcoming paper we will explore various taxonomic options and the associated problems with each of them in a revised generic classification.

\section{Acknowledgments}

We would like to thank two anonymous reviewers, and the editorial team, for constructive criticism of the manuscript. In South Africa we are grateful to the South African National Biodiversity Institute for financial support, the Western Cape, Northern Cape and KwaZulu-Natal Nature Conservation Boards for granting collecting permits. From NZ we would like to thank Heidi Meudt and Phil Garnock-Jones for mentoring JMP, Lesley Bagnall, Phil Garnock-Jones, Mark Prebble, Gesine Pufal and Hugh Wilson for help collecting specimens and to gratefully acknowledge financial support from the Auckland Botanical Society (Lucy Cranwell field grant), Museum of New Zealand Te Papa Tongarewa (Te Papa MSc Scholarship in Molecular Systematics), and Victoria University of Wellington (Masters Scholarship and research funding). 


\section{Literature Cited}

Adamson, R. S. 1950. Campanulaceae, Treichelia. P.745 in Flora of the Cape Peninsula, eds. R.S. Adamson and T.M. Salter. Cape Town: Juta.

Adamson, R. S. 1952. A revision of the genera Prismatocarpus and Roella. Journal of South African Botany 17: 93-130.

Adamson, R. S. 1955. The phytogeography of Roella and Prismatocarpus. Svensk Botanisk Tidskrift 49: 24-28.

Akaike, H. 1974. A new look at the statistical model identification. IEEE Transactions on Automatic Control 19: 716-723.

Albach, D. C., M. M. Mart'́nez-Ortega, M. A. Fischer, and M. W. Chase. 2004. A new classification of the tribe Veroniceae-problems and a possible solution. Taxon 53:2 429-452.

APG. 2003. An update of the Angiosperm Phylogeny Group classification for the orders and families of flowering plants: APG II. Botanical Journal of the Linnean Society 141: $399-436$.

Antonelli, A. 2008. Higher level phylogeny and evolutionary trends in Campanulaceae subfam. Lobelioideae: molecular signal over-shadows morphology. Molecular Phylogenetics and Evolution 46: 1-18. Axelrod, D. L. and P. H. Raven. 1978. Late Cretaceous and Tertiary vegetation history of Africa. Pp. 77-130 in Biogeography and ecology of southern Africa, ed. M. J. A Werger. The Hague: Junk.

Backlund, A. and K. Bremer. 1998. To be or not to be - principles of classification and monotypic plant families. Taxon 47: 391-400.

Baldwin, B. G. 1992. Phylogenetic utility of the internal transcribed spacers of nuclear ribosomal DNA in plants: an example from the Compositae. Molecular Phylogenetics and Evolution 1: 3-16.

Brummitt, R. K. 2006. Am I a bony fish? Taxon 55:2 268-269.

Cosner, M. E., L. A. Raubeson, and R. K. Jansen. 2004. Chloroplast DNA rearrangement in Campanulaceae: phylogenetic utility of highly rearranged genomes. BMC Evolutionary Biology 4: 27. doi:10.1186/ 1471-2148-4-27

Cronquist, A. 1981. An integrated system of classification of flowering plants. New York: Columbia University Press.

Cupido, C. N. and F. Conrad. 1999. Bellflowers-Getting to know the South African bellflowers. Veld \& Flora 85: 180-181.

Cupido, C. N., W. M. M. Eddie, and L. R. Tiedt. 2011. Systematic and ecological significance of seed coat morphology in South African Campanulaceae sensu stricto. Edinburgh Journal of Botany 68: 1-21.

Cupido, C. N. 2006. A taxonomic revision of the genus Merciera (Campanulaceae). Bothalia 36: 1-11.

Cupido, C. N. 2009. Systematic studies of the South African Campanulaceae sensu stricto with an emphasis on generic delimitation. Ph. D. thesis, Cape Town: University of Cape Town.

Cupido, C. N. 2011. A new species of Wahlenbergia from Western Cape, South Africa. Bothalia 41: 178-181. 
Dolphin, K., R. Belshaw, C. D. L. Orme, and D. L. J. Quicke. 2000. Noise and incongruence: interpreting results of the incongruence length difference test. Molecular Phylogenetics and Evolution 17: 401-406.

Doyle, J. J. and J. L. Doyle. 1987. A rapid DNA isolation procedure for small quantities of fresh leaf tissue. Phytochemical Bulletin 19: 11-15. Doyle, J. J. and J. L. Doyle. 1990. Isolation of plant DNA from fresh tissue. Focus (San Francisco, Calif.) 12: 13-15.

Eddie, W. M. M., C. N. Cupido, and J. J. Skvarla. 2010. Pollen and reproductive morphology of Rhigiophyllym and Siphocodon (Campanulaceae): two unique genera of the fynbos vegetation of South Africa. Bothalia 40: 103-115.

Eddie, W. M. M., T. Shulkina, J. Gaskin, R. C. Harberle, and R. K. Jansen. 2003. Phylogeny of Campanulaceae s.str. inferred from ITS sequences of nuclear ribosomal DNA. Annals of the Missouri Botanical Garden 90: 554-575.

Farris, J. S. 1989. The retention index and rescaled consistency index. Cladistics 5: 417419.

Farris, J. S., M. Källersjo, A. G. Kluge, and C. Bult. 1995. Constructing a significance test for incongruence. Systematic Biology 44: 570-572.

Felsenstein, J. 1985. Confidence limits on phylogenies: an approach using the bootstrap. Evolution 39: 783-793.

Fitch, W. M. 1971. Toward defining the course of evolution: minimum change for a specified tree topology. Systematic Zoology 20: 406-416. Gardner, R. O. 2007. Hebe and Hera. New Zealand Botanical Society Newsletter 89: 14-15.

Garnock-Jones, P. J., D. Albach, and B. Briggs. 2007. Botanical names in Southern Hemisphere Veronica (Plantaginaceae): Sect. Detzneria, sect. Hebe, and sect. Labiatoides. Taxon 56:2 571-582.

Garnock-Jones, P. J. and D. Albach. 2008. Veronica and Hebe: a response to Rhys Gardner. New Zealand Botanical Society Newsletter 90: 12-14.

Gustafsson, M. H. G. and K. Bremer. 1995. Morphology and phylogenetic interrelationships of the Asteraceae, Calyceraceae, Campanulaceae, Goodeniaceae, and related families (Asterales). American Journal of Botany 82: 250-265.

Harberle, R. C., A. Dang, T. Lee, C. Peň aflor, H. Cortes-Burns, A. Oestreich, L. Raubeson, N. Cellinese, E. J. Edwards, S. Kim, W. M. M. Eddie, and R. K. Jansen. 2009. Taxonomic and biogeographic implications of a phylogenetic analysis of the Campanulaceae based on three chloroplast genes. Taxon 58: 715-734.

Hilliard, O. M. and B. L. Burtt. 1973. Notes on some plants of southern Africa chiefly from Natal: Craterocapsa. Notes from the Royal Botanic Garden Edinburgh 32: 314-326.

Holmgren, P. K., N. H. Holmgren, and L. C. Barnet. 1990. Index herbariorum. New York Botanical Garden, Bronx, New York.

Hong, D.-Y. 1995. The geography of the Campanulaceae: on the distribution centres. Acta Phytotaxonomica Sinica 33: 521-536.

Hong, D.-Y. and K.-Y. Pan. 1998. The restoration of the genus Cyclocodon (Campanulaceae) and its evidence from pollen and seed-coat. Acta Phytotaxonomica Sinica 36: 106110 .

Huelsenbeck, J. P. and F. Ronquist. 2001. Mr Bayes: Bayesian inference of phylogeny. Bioinformatics 17: 754-755.

\section{http://repository.uwc.ac.za}


Kennet, J. P. 1980. Paleoceanographic and biogeographic evolution of the Southern Ocean during the Cenozoic, and Cenozoic microfossil datums. Palaeogeography, Palaeoclimatology, Palaeoecology 29: 125-141. Kluge, A. G. 1989. A concern for evidence and the phylogenetic hypothesis of relationship among Epicrates (Boidae, Serpentes). Systematic Zoology 38: 7-25.

Kluge, A. G. and J. S. Farris. 1969. Quantitative phyletics and the evolution of anurans. Systematic Zoology 18: 1-32.

Kumar, S., K. Tamura, and M. Nei. 2004. MEGA3: Integrated software for molecular evolutionary genetics analysis and sequence alignment. Briefings in Bioinformatics 5: $150-163$.

Lammers, T. G. 1992. Circumscription and phylogeny of the Campanulales. Annals of the Missouri Botanical Garden 79: 388-413.

Lammers, T. G. 2007. World checklist and Bibliography of Campanulaceae. Kew: Royal Botanic Gardens.

Levyns, M. R. 1964. Presidential address, migrations and origin of the Cape flora. Transactions of the Royal Society of South Africa 37: 86-107. Linder, H. P. 2003. The radiation of the Cape flora, southern Africa. Biological Reviews of the Cambridge Philosophical Society 78: 597-638.

Linder, H. P. and C. R. Hardy. 2004. Evolution of the species -rich Cape flora. Philosophical Transactions of the Royal Society of London. Series B, Biological Sciences 359: 16231632.

Marloth, R. 1932. The flora of South Africa, vol. 3. Wheldon and Wesley: London.

McVaugh, R. 1945. The genus Triodanis Rafinesque, and its relationships to Specularia and Campanula. Wrightia 1: 13-52.

Miller, R. E., J. A. McDonald, and P. S. Manos. 2004. Systematics of Ipomoea subgenus Quamoclit (Convolvulaceae) based on ITS sequence data and a Bayesian phylogenetic analysis. American Journal of Botany 91: 1208-1218.

Nixon, K. C. and J. M. Carpenter. 1996. On simultaneous analysis. Cladistics 12: 221-241.

Park, J.-M., S. Kovacic, Z. Liber, W. M. M. Eddie, and G. M. Schneeweiis. 2006. Phylogeny and biogeography of isophyllous species of Campanula (Campanulaceae) in the Mediterranean area. Systematic Botany 31: 862-880.

Petterson, J. A. 1997. Revision of the genus Wahlenbergia (Campanulaceae) in New Zealand. New Zealand Journal of Botany 35: 9-54.

Posada, D. and K. A. Crandall. 1998. Modeltest: testing the model of DNA substitution. Bioinformatics 14: 817-818.

Phillips, E. P. 1927. Description of three new South African plants. Bothalia 2: 368396.

Plunkett, G. T., J. J. Bruhl, and I. R. H. Telford. 2009. Two new, sympatric species of Wahlenbergia (Campanulaceae) from the New England Tableland escarpment, New South Wales, Australia. Australian Systematic Botany 22: 319-331.

Prebble, J. M., C. N. Cupido, H. M. Meudt, and P. J. Garnock-Jones. 2011. First phylogenetic and biogeographical study of the southern blue-bells (Wahlenbergia, Campanulaceae). Molecular Phylogenetics and Evolution 59: 636-648. 
Prebble, J. M., H. M. Meudt, and P. J. Garnock-Jones. 2012. An expanded molecular phylogeny of the southern bluebells (Wahlenbergia, Campanulaceae) from Australia and New Zealand. Australian Systematic Botany 25: 11-30.

Ram'irez, M. J. 2006. Further problems with the incongruence length test: "hypercongruence" effect and multiple comparisons. Cladistics 22: 289-295.

Reeves, G., M. W. Chase, P. Goldblatt, P. Rudall, M. F. Fay, A. V. Cox, B. Lejeune, and T. Souza-Chies. 2001. Molecular systematics of Iridaceae: evidence from four plastid DNA regions. American Journal of Botany 88: 2074-2087.

Roquet, C., L. Sá ez, J. J. Aldasoro, A. Susanna, M. L. Alarcó n, and N.

Garcia-Jacas. 2008. Natural delineation, molecular phylogeny and floral evolution in Campanula. Systematic Botany 33: 203-217.

Schö nland, S. 1889. Campanulaceae. Pp 40-70 in Die natü rlichen Pflangen-familien IV, eds A Englers and K. Prantl. Leipzig: Engelman.

Shetler, S. G. and N. R. Morin. 1986. Seed morphology in North American Campanulaceae. Annals of the Missouri Botanical Garden 73: 635-688.

Smith, P. J. 1992. A revision of the genus Wahlenbergia (Campanulaceae) in Australia. Telopea 5: 91-175.

Swofford, D. L. 2003. PAUP*: Phylogenetic analysis using parsimony (*and other methods) Version 4.ob10. Sunderland: Sinauer Associates.

Taberlet, P., L. Gielly, G. Pauton, and J. Bouvet. 1991. Universal primers for amplification of three non-coding regions of chloroplast DNA. Plant Molecular Biology 17: 11051109.

Thulin, M. 1974. Gunillaea and Namacodon. Two new genera of Campanulaceae in Africa. Botaniska Notiser 127: 165-182.

Thulin, M. 1975. The genus Wahlenbergia s.l. (Campanulaceae) in Tropical Africa and Madagascar. Symbolae Botanicae Upsalienses 21: 97-105.

Wagstaff, S. J. and P. J. Garnock-Jones. 1998. Evolution and biogeography of the Hebe complex (Scrophulariaceae) inferred from ITS sequences. New Zealand Journal of Botany 36: 425-437.

Wellman, W. G. and C. N. Cupido. 2003. Campanulaceae. Pp.336-346 in Plants of southern Africa, eds. G. Germishuizen and N.L. Meyer. Strelitzia 14. Pretoria: National Botanical Institute.

Wiens, J. J. 1998. Combining data sets with different phylogenetic histories. Systematic Biology 47: 568-581.

Yoder, A. D., J. A. Irwin, and B. A. Payseur. 2001. Failure of the ILD to determine data combinability for slow loris phylogeny. Systematic Biology 50: 408-424.

Zachos, J., M. Pagani, L. Sloan, E. Thomas, and K. Billups. 2001. Trends, rhythms, and aberrations in global climate 65 ma to present. Science 292: 686-693.

Appendix 1. Taxa, voucher/source (locality, collector and collecting number, herbarium where specimen is housed or references in the case of published sequences) and GenBank accession numbers (trnL-F, ITS) for sequences used in this study, -indicates a sequence not available, * indicates no accession number allocated as the sequence is less than $200 \mathrm{bp}$. 
Ingroup-Craterocapsa congesta Hilliard \& Burtt, South Africa, ITS Eddie et al. (2003), -, AY322049; C. montana (A. DC.) Hilliard \& Burtt, South Africa, Eastern Cape, Keiskamahoek, Goldblatt s. n., NBG, KCo13605, KCo13664; C. tarsodes Hilliard \&Burtt, South Africa, KwaZulu-Natal, Himeville, Cupido 306, NBG, KC013606, KC013665; Merciera azurea Schltr., South Africa, Western Cape, Bredasdorp, Cupido 111, NBG, KC013607, KCo13666; M. brevifolia A. DC., South Africa, Western Cape, Caledon, Cupido 235, NBG, KC013608, KC013667; M. eckloniana H. Buek, South Africa, Western Cape, Villiersdorp, Cupido 76, NBG, KCo13609, KCo13668; M. leptoloba A.DC., South Africa, Western Cape, Bredasdorp, Cupido 108, NBG, KC013610, KC013669; Microcodon glomeratus A. DC., South Africa, Western Cape, Kraaifontein, Cupido 105, NBG, KCo13611, KC013670; M. hispidulus (L. f.) Sond., South Africa, Western Cape, Malmesbury, Cupido 82, NBG, KCo13614, -; $M$. sp.1, South Africa, Western Cape, Clanwilliam, Cupido 257, NBG, KCo13612, -; M. sp.2 'sparsiflorus', South Africa, Western Cape, Hopefield, Cupido 197, NBG, KC013613, KC013671; Prismatocarpus brevilobus A. DC., South Africa, Western Cape, Darling, Duckitt s. n., NBG, KCo13615, KCo13672; P. campanuloides (L. f.) Sond., South Africa, Western Cape, Genadendal, Cupido 219, NBG, KC013616, KC013673; P. crispus L'Hé r., South Africa, Western Cape, Clanwilliam, Manning 2651E, NBG, KCo13617, KC013674; P. diffusus (L. f.) A. DC., South Africa, Western Cape, Genadendal, Cupido 220, NBG, KC013618, KC013675; P. fruticosus L'Hér., South Africa, Western Cape, Somerset West, Cupido 118, NBG, KC013619, KC013676; P. nitidus L'He' r., South Africa, Western Cape, Cape Town, Cupido 228, . NBG, KC013620, KC013677; P. pedunculatus (P. J. Bergius) A. DC., South Africa, Western Cape, Citrusdal, Cupido273, NBG, KCo13621, KC013678; P. schlechteri Adamson, South Africa, Western Cape, Caledon, Cupido237, NBG, KC013622, KC013679; P.sessilis Eckl. ex A. DC., South Africa, Western Cape, Bredasdorp, Cupido 112, NBG, KC013623, KC013680; P. sp. 'Vil', South Africa, Western Cape, Villiersdorp, Cupido 241, NBG, KCo13624, -; Rhigiophyllum squarrosum Hochst., South Africa, Western Cape, Napier, Cupido 106, NBG, KC013625, KC013681; Roella amplexicaulis Wolley-Dod, South Africa, Western Cape, Cape Town, Cupido 122, NBG, KC013626, KC013682; R. arenaria Schltr.; South Africa, Western Cape, Napier, Cupido s. $n$., NBG, KC013627, KCo13683; $R$. ciliata L., South Africa, Western Cape, Cape Town, Cupido 213, NBG, KCo13628, -; R. ciliata L., South Africa, ITS Eddie et al. (2003), -, AY322074; R. cuspidata Adamson, South Africa, Western Cape, Caledon, Cupido 234, NBG, KCo13629, KCo13684; R. incurva A. DC., South Africa, Western Cape, Hermanus, Cupido 20O, NBG, KC013630, KC013685; R. muscosa L.f., South Africa, Western Cape, Cape Town, Cupido 232, NBG, KCo13631, KCo13686; R. prostrata E. Mey. ex A. DC., South Africa, Western Cape, Malmesbury, Cupido 208, NBG, KC013632, KCo13687; R. psammophila Schltr., South Africa, Western Cape, Genadendal, Cupido 216, NBG, KCo13633, KCo13688; $R$. secunda H. Buek, South Africa, Eastern Cape, Joubertina, Cupido 285, NBG, KCo13634, KCo13689; R. spicata L. f., South Africa, Western Cape, Elim, Cupido 245, NBG, KCo13635, KCo13690; R. squarrosa P. J. Bergius, South Africa, Western Cape, Cape Town, Cupido 229, NBG, KCo13636, KCo13691; R. triflora (R. D. Good) Adamson, South Africa, Western Cape, Cape Town, Cupido 226, NBG, KCo13637, -; R. sp. 'Genadendal', South Africa, Western Cape, Genadendal, Cupido 223, NBG, KCo13638, KC013692; Siphocodon debilis Schltr., South Africa, Western Cape, Napier, Cupido 139, NBG, KCo13639, *; S. 
spartioides Turcz., South Africa, Western Cape, Villiersdorp, Cupido 133, NBG, KCo13640, KC013693; Treichelia dodii Cupido, South Africa, Western Cape, Malmesbury, Cupido 83, NBG, KC013641, KC013694; T. longibracteata (H. Buek) Vatke, South Africa, Western Cape, Hermanus, Cupido 199, NBG, KC013642, KCo13695; Theilera guthriei (L. Bolus) Phillips, South Africa, Western Cape, Prins Albert, Cupido 279, NBG, KCo13643, KCo13696; T. robusta (A. DC.) Cupido, South Africa, Eastern Cape, Willowmore, Cupido 317, NBG, KCo13644, KC013697; Wahlenbergia acaulis E. Mey., South Africa, Northern Cape, Kamiesberg, Cupido 267, NBG,HQ823495, HQ823460; W. adpressa (Thunb.) Sond., South Africa, Western Cape, Hopefield, Cupido 21O, NBG, HQ823496, HQ823461; W. akoroa J. A. Petterson, New Zealand, Banks Peninsula, Palm Gully, Wilson 2, WELT, HQ823497, HQ823436; W. albomarginata Hook. subsp. albomarginata, New Zealand, Cantebury, Mt. Cook, JMP o994, WELT, HQ823498, HQ823437; W. androsacea A. DC., South Africa, Western Cape, Melkbos, Cupido 183, NBG, HQ823499, HQ823462; W. annularis A. DC.,South Africa, Western Cape, Elandsbaai, Cupido 251, NBG, HQ823500, HQ823463; W. appressifolia Hilliard \& Burtt, South Africa, KwaZulu-Natal, Himeville, Cobhan, Cupido 358, NBG, KCo13645, KCo13698; W. axillaris Sond., South Africa, Western Cape, Bredasdorp, Cupido 107, NBG, HQ823501, HQ823464; W. buseriana Schltr. \& Brehmer, South Africa, Northern Cape, Platbakkies, Cupido 263, NBG, KCo13646, -; W. capensis (L.) A. DC., South Africa, Western Cape, Malmesbury, Cupido 184, NBG, HQ823502, HQ823465; W. capillacea (L. f.) A. DC., South Africa, Cupido 313, Western Cape, Uniondale, NBG, HQ823503, HQ823466; W. cartilaginea Hook. f., New Zealand, Hanmer Springs, Island Saddle, JMP o9117c, WELT, HQ823504, HQ823438; W. ceracea Loth., Australia, NSW, Kosciuszko NP, summit Mt Kosciuszko, JMP o944, WELT, HQ823505, HQ823439; W. cernua (Thunb.) A. DC., South Africa, Western Cape, Cape Town, Cupido 188, NBG, HQ823506, HQ823467; W. cinerea (L. f.) Sond., South Africa, Western Cape, Genadendal, Cupido 222, NBG, HQ823507, HQ823468; W.communis Carolin, Australia, NSW, Cooma, JMP o964, WELT, HQ823508, HQ823440; W. cuspidata Brehmer, South Africa, KwaZulu-Natal, Himeville, Cupido 302, NBG, HQ823509, HQ823469; W. densifolia Loth., Australia, NSW, Kosciuszko NP, Rennix walk, JMP o934, WELT, HQ823510, HQ823441; W. depressa J. M. Wood \& M. S. Evans, South Africa, Free State, Baker's Kop, Roux 335o, NBG, HQ823511, HQ823470; W. desmantha Lammers, South Africa, Western Cape, Albertinia, Cupido 310, NBG, HQ823512, HQ823471; W. ecklonii H. Buek, South Africa, Western Cape, Paarl, Cupido 206, NBG, HQ823514, HQ823472; W. exilis A. DC., South Africa, Western Cape, Malmesbury, Cupido 81, NBG, HQ823515, HQ823473; W. fruticosa Brehmer, South Africa, Western Cape, Riversdale, Cupido 311, NBG, HQ823517, HQ823474, W. gracilis (Forster. f.) A. DC., Australia, NSW, Blue Mts, JMP o902, WELT, HQ823519, HQ823445; W. gloriosa Loth., Australia, NSW, Kosciuszko NP, Diggers Ck, JMP 0939, WELT, HQ823518, HQ823444; W. hederacea L., Europe, trnL-F Roquet et al. (2008), ITS Eddie et al. (2003), EFo88792, AY322080; W. huttonii (Sond.) Thulin, South Africa, KwaZulu-Natal, Himeville, Cupido 304, NBG, KCo13647, KC013699; $W$. juncea (H. Buek) Lammers, South Africa, Eastern Cape, Sterkstroom, Cupido 296, NBG, KCo13648, -; W. krebsii Cham., South Africa, Eastern Cape, Hogsback, Cupido 294, NBG, HQ823521, HQ823475; W. littoricola P. J. Smith, Australia, Victoria, Mt Buffalo, Petterson 1, WELT, HQ823523, -; W. lobelioides (L. f.) Link, Europe/Africa. trnL-F Roquet et al. 
(2008), EFo88793, -;W. lobulata Brehmer, South Africa, KwaZulu-Natal, Himeville, Sani Pass, Cupido 352, NBG, KCo13649, KC013700; W. longifolia A. DC., South Africa, Western Cape, Darling, Cupido 212, NBG, HQ823524, HQ823476; W. luteola P. J. Smith, Australia, NSW, Abercrombie Caves, JMP o911, WELT, HQ823525, HQ823448; W. neoridiga Lammers, South Africa, Western Cape, Prins Albert, Cupido 278, NBG, HQ823527, HQ823477; W. nodosa H. Buek, South Africa, Western Cape, Worcester, Cupido 144, NBG, KC013650, -; W. oxyphylla A. DC., South Africa, Western Cape, Vanrhynsdorp, Cupido 259, NBG, HQ823529, HQ823478; W. paniculata (Thunb.) A. DC., South Africa, Western Cape, Yzerfontein, Cupido 181, NBG, HQ823530, HQ823479; W. parvifolia (P. J. Bergius) Adamson,South Africa, Western Cape, Cape Town, Cupido 119, NBG, HQ823531, HQ823480; W. pilosa H. Buek, South Africa, Northern Cape, Calvinia, Cupido 272, NBG, -, KC013701; W. polyantha Lammers, South Africa, Western Cape, Albertinia, Cupido 287, NBG, HQ823532, HQ823481; W. polytrichifolia Schltr., Lesotho, Top of Sani Pass, Cupido 349, NBG, KCo13651, KC013702; W. procumbens (Thunb.) A. DC., South Africa, Western Cape, Napier, Cupido 244, NBG, HQ823533, HQ823482; W. psammophila Schltr., South Africa, Western Cape, Vanrhynsdorp, Cupido 26o, NBG, HQ823534, HQ823483; W. pymaea Colenso subsp. pygmaea, New Zealand, Central Plateau, Mt. Ruapehu, Ohakune Rd, PGJ 2770a, WELTU, HQ823535, HQ823451; W. ramosa G. Simpson, New Zealand, Wellington, Pukerua Bay, JMP o9105a, WELT, HQ823536, HQ823452; W. ramulosa E. Mey., South Africa, Western Cape, Clanwilliam, Cupido 256, NBG, KCo13652, -; W. rubioides A. DC., South Africa, Western Cape, Genadendal, Cupido 215, NBG, KCo13653, -; W. stellarioides Cham. \& Schltdl., South Africa, Eastern Cape, Sterkstroom, Cupido 295, NBG, KC013654, -; W. squamifolia Brehmer, South Africa, Free State, Harrismith, Bezuidenhouts Pass, Cupido 342, NBG, KCo13655, KC013703; W. subulata (L'Hé r.) Lammers, South Africa, Western Cape, Somerset West, Cupido 207, NBG, HQ823541, HQ823484; W. suffruticosa Cupido, South Africa, Western Cape, Malmesbury, Cupido 209, NBG, KC013656, KCo13704; W. tenella (L. f.) Lammers, South Africa, Western Cape, Cape Town, Cupido 194, NBG, HQ823544, HQ823485; W. tenerrima H. Buek, South Africa, Western Cape, Prins Albert, Cupido 277, NBG, HQ823545, HQ823486; W. thunbergiana H. Buek, South Africa, Western Cape, Elandsbaai, Cupido 25o, NBG, HQ823546, HQ823487; $W$. thunbergii (Schult.) B. Nordenstam, South Africa, Eastern Cape, Port Elizabeth, Forest s. n., NBG, -, KC013705; W. undulata (L. f.) A. DC., South Africa, Eastern Cape, Hogsback, Cupido s. n., NBG, HQ823547, HQ823488; W. unidentata (Thunb.) A. DC., South Africa, Western Cape, Caledon, Cupido 274, NBG, KCo13657, -; W. violacea J. A. Petterson, New Zealand, Nelson area, Dun Mts, JMP 0972, WELT, HQ823549, HQ823459; W. virgata Engl., South Africa, KwaZulu-Natal, Himeville, Cupido 299, NBG, HQ823550, HQ823489; W. sp. 'Sani Rd', South Africa, KwaZulu-Natal, Sani Road, Cupido 309, NBG, HQ823539, - .

Outgroup-Azorina vidalii (Wats.) Feer, trnL-F Roquet et al. (2008), ITS Eddie et al. (2003), EFo88696, AY322007; Campanula divaricata Michx., trnL-F Roquet et al. (2008), ITS Eddie et al. (2003), EFo88718, AY322014; C. latifolia L., trnL-F Roquet et al. (2008), ITS Eddie et al. (2003), EFo88732, AY322024; Canarina canariensis (L.) Vatke, trnL-F Roquet et al. (2008), ITS Eddie et al. (2003), EFo88777, AY322045; Cyphia bulbosa (L.) P. J. Bergius, South Africa, Western Cape, Cape Town, Cupido s. n., NBG, KCo13658, -; 
C. comptonii Bond, South Africa, Western Cape, Katbakkies, Manning s. n., NBG, KCo13659, KCo13706; C. volubilis (Burm. f.) Willd., South Africa, Western Cape, Paarl, Cupido 249, NBG, KCo13660, -; Jasione montana L., trnL-F Antonelli (2008), ITS Park et al. (2006), DQ356174, DQ304566; Lobelia comosa L., South Africa, Western Cape, Cape Town, Cupido s. n., NBG, KC013661, KC013707; L. coronopifolia L., South Africa, Western Cape, Villiersdorp, Mannie s. n., NBG, -, KC013709; L. jasionoides (A. DC.) E. Wimm., South Africa, Western Cape, Cape Town, Cupido 12O, NBG, KCo13662, KC013708; Monopsis debilis (L. f.) C.Presl, South Africa, Western Cape, Stellenbosch, Cupido s. n., NBG, KCo13663, -; Platycodon grandiflorus (Jacq.) A. DC., trnL-F Roquet et al. (2008), ITS Eddie et al. (2003), EFo88788, AY322073. 